\title{
Religion and Secularity: The New Testament Perspective
}

\author{
Ven. Dr. Sola Igbari \\ Crowther Graduate Theological Seminary, Abeokuta, Nigeria \\ Email: solaigbari@yahoo.com
}

Received 10 April 2016; accepted 24 April 2016; published 28 April 2016

Copyright (C) 2016 by author and OALib.

This work is licensed under the Creative Commons Attribution International License (CC BY). http://creativecommons.org/licenses/by/4.0/

(c) (†) Open Access

\section{Abstract}

For many years in the history of humans, there had been conflicting views of the relationship between religion and secularity. Some adherents decry the fact that religion should have any relation with the secular because religion is entirely metaphysical while secularity relates to mundane things. In modern scholarship, this issue has continued to engage the attention of scholars, practioners of religion, individuals and the general public. Religion has both negative and positive dimensions. It is God's gift to humans to be utilized for the betterment of the human society. Religion is also a veritable tool to advance the course of secularity in the world to accomplish God's purpose of creation. Hence this paper examines the modern man as a religionist in relation to the secular world where he lives and fulfils his destiny. In an attempt to achieve this objective, the New Testament perspective of the relationship between religion and secularity is what this paper tried to achieve so as to strengthen the fact that a Christian cannot be totally independent from the secular world where he lives and fulfils his purpose in life. In Pauline theology on religion and secularity, Christian has a vital role to play in bringing sanity to the secular world where he belongs by putting into practice the tenets of his faith so also, it is expected that he enjoys maximally certain amenities and privileges which are provided by the secular world. It is obvious that one cannot do without the other.

\section{Keywords}

Religion, Secularity, Religionist

Subject Areas: Philosophy, Sociology

\section{Introduction}

This paper is an attempt to examine the modern man as a religionist and his relationship with the immediate environment vis-à-vis what the New Testament teaches on Church and the secular world. But before we go to the 
heart of the title of this paper, we need to examine the key words such as Religion and Secularity.

\section{What Is Religion?}

The words "religion" and "religious" seldom appear in the scripture. This is at least partially because Biblical faith is best understood as a relationship and thus stands in distinction from all the religions of the world [1]. However, where the word "religion" is found in the New Testament, several different Greek words are used. For instance, in Acts 25: 19 Judaism is called by an outsider $\delta \varepsilon \iota \sigma ı \delta \alpha \gamma v o v i \alpha$ which simply means "religion". The

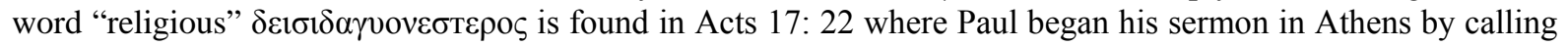
attention to evidence that the Greeks were "very religious" [1].

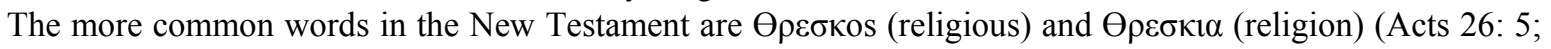
Col. 2: 18; James 1: 26 \& 27). They all focus attention on the outward rituals and rites of ceremonial religions. "Religion" emphasizes piety in every kind of relationship that makes the adherents godly.

Religion is historical in the sense that it arises as the consequence of certain events in history and in the sense that its shape and content are determined by these events.

Religion implies no metaphysical scheme and no mythological world-view. Religion cannot be identified with a philosophy, for it is a historical reality which carries its understanding of the ultimate reality, the world and the self in itself.

It therefore involves response and mutuality. There is dependence as well as responsibility. Geoffrey Parrinder [2] defines religion as:

The recognition of superhuman controlling power, and especially of a personal God, entitled to obedience.

Belief in God or gods is found in most Religions. It is universal, is at all stages of history and human geography. According to Parrinder [2] [3], the study of religion reveals that an important feature of it is a longing for value in life, a belief that life is not accidental or meaningless. He goes on further to say:

The search for meaning leads to faith in a power greater than man, and finally to a universal or superhuman mind which has the intention and will to maintain the highest values for human life. There is an intellectual element in religious search for purpose and value, and an emotional element in the dependence upon the power which creates or guarantees those values.

A philosopher, A.N. Whitehead citing Parrinderdefines religion as what "the individual does with his own solitariness" [2]-[4]. This definition seems to be incomplete in the sense that religion always has a social content and it is expressed in patterns of behaviour. Sometimes there is a strong organisation, such as a church or mosque while at other times the model of religious life may be that of a lonely ascetic life in the forest.

Herbert Spencer citing Parrinder says that "Religion had its origins in vision or appearance of the ghost of the dead, and these ancestors were worshipped as god" [2]-[5]. This is somehow true of what religion is. While Emile Durkheim in his book on "The Elementary Forms of Religionist Life" says "Religion is a social fact and not simply the product of psychology of certain individuals". According to him, "It could not be an illusion, for religion was universal and had appeared in every age, producing great cultures and systems of morality and law" [6].

With the above definitions from different scholars one can infer that religion is as old as man, therefore, it is an essential part of human survival.

\section{What Is Secularity?}

The word saeculum in classical Latin mean "generation", "age”, "long period of time" [7]. In Christian usage saeculum came to mean "the world as opposed to the Church" [7]. Similarly, in England, we find as early as 1290 the attested usage of "secular" meaning "belonging to the world, as distinct from the Church and religion", civil, lay, temporal, chiefly with the negative sense of "non-ecclesiastical, non-religious or non-sacred" [7] [8]. Secularity is a political concept characterized with political powers independent of religious affiliation which distinguished religion as man's "inward" affair from his "outward" political and civil status. Hence, a secularist is one who gives primary attention to those subjects, the issue of which can be tested by the experience of this life. The secularist principle that precedence should be given to the duties of this life over those, which pertain to another world. The point in this argument is that attention to temporal thing is based upon practical experience 
of the living interests of the hour, whereas religion is a matter of speculation.

Secular civilization therefore, according to Ronald Smith has provided a satisfying opportunity for personal development, not only in pursue of truth, but also in the provision of outlets for activities which supply all the values which religion was accustomed to provide [7]-[9].

Rufus M. Jonesin his work "Secular Civilisation and the Christian Task" defines secularism by citing Ronald Smith as "a way of life and an interpretation of life that includes only the natural order of things and that do not find God, or a realm of spiritual reality, essential of life and thought” [7]-[9]. This definition distinguished secularity from religion. It sees secularity independent of Religion.

Harvey Cox, a one time Bishop of Woolwich defines secularity as the liberation of man from religious and metaphysical tutelage, the turning of his attention away from other world and toward this one [10].

Secularization, as the German theologian Friedrich Cogarten defined it, "Is the legitimate consequence of the impact of biblical faith on history" [11]. This is why it is not mere accident that secularization arose first within the culture of the so-called Christian west, in the history which the biblical religions have made their most telling impact.

The rise of natural science, of democratic political institutions and of cultural pluralism, all developments we normally associate with western culture can scarcely be understood without the original impetus of the Bible. To confirm this statement thus Harvey Cox says "the disenchantment of nature beings with the creation, the descralisation of politics with the Exodus; and the deconsecration of values with the Sinai covenant especially with its prohibition of idols" [10].

Hence what secularity is can be most understood when you compare it with what Religion contains and the tenets of the two. From the very beginning of its usage, secularity denoted something vaguely inferior; it meant "this world" of change as opposed to the eternal "religious world" [10] [12]. This usage already signifies an ominous departure from biblical categories. It implies that the true religious world is timeless, changeless, and thus superior to the "Secular" world which was passing and transient. Gradually the meaning of the term secularity was widened, when the separation Pope and emperor became a fact of life in Christendom, the division between the spiritual and the secular assumed institutional embodiment, soon, the passing of certain responsibilities from ecclesiastical to political authorities was designated "Secularisation".

More recently, secularization has been used to describe a process on the cultural level which is parallel to the political one. It denotes the disappearance of religious determination of the symbols of cultural integration. Cultural secularity is an inevitable concomitant of a political and social secularization. In the United States there has been considerable degree of secularization for many years. The public schools are officially secular in the sense of being free from church control.

In any case, secularity as a descriptive term has a wide and inclusive definition. It appears in many guises, depending on the religious and political history of the area concerned. In Bernard Haring [13] view, sin is not seen as inimical to moral growth of the society while in a religious setting sin is punishable. In summary, secularity presupposes a life style that is devoid of religious discipline or demands moral values.

\section{Religion in New Testament Context}

It is a biblical fact that Christianity is an off shoot of Judaism. The Old Testament religion was Judaism. This religion had its own tenets which Jews of today still hold tenaciously onto. But the fact remains that Christianity developed as independent of Judaism with the revolution brought by the emergence of Jesus Christ with his distinctive teachings e.g. Matt. 5 - 7; cf I Thess. 1: 1ff. Undoubtedly this phenomenon occurred outside Palestine, but it was parallel to the formation of identifiable groups of Jewish Christians within Palestine [14].

Jabnes fixation of a canon of scripture developed partially as a response to the Christian movement. Hence, it was imperative for a Judaism that wanted to build a fence around the law to exclude from its ambiance Christian "prophetic" and "apocalyptic" writings [14].

With Christianity, almost as venerated in form as was Judaism of the first century, there developed an ever increasing esteem for the letters that had been written by Paul, the writing that gave testimony to Jesus, and texts that emanated from Christian prophets.

According to Raymond Collins, we ought not to arrive quickly at the conclusion that the Christian communities of the late first century and the beginning of the second century were eager to qualify the documents produced by Christian writing as scripture [14]. In fact, the opposite would seem to be the case. There was a reluc- 
tance to equate Christian writing with the scriptures. This reluctance was due, first of all, to the act that the Christian churches of the first several generations already possessed "the scriptures". These scriptures $\alpha$ l' $\gamma \rho \alpha \theta \alpha$ l were those writings traditionally identified as the scriptures.

In the New Testament period there were many religious movements such as Gnosticism, Epicureanism stoicism, that were threats to the spread of Christianity during the evangelistic travels of St. Paul, the Apostle.

The Christian faith met with these religions that posed some threats which Paul had to combat in an aggressive manner in the early church. An example of this was his attack on the Athenians in Acts 17: 22ff where Paul discovered an altar with an inscription "To an unknown god". He observed that Athenians were religious but that they worshipped idols not the Supreme God. This was his point of approach to the way he presented the gospel to them. The God they did not know was the God he brought to them teaching them that God does not live in shrines made by man but He is the Lord of heaven and earth (Acts 17: 24).

The New Testament made clear the distinction between Christianity and other religions that exited in the history of the church. Hence, through the preaching of the apostles the superiority of Christian religion was firmly established by the Apostle in their Missionary outreaches. The writer of the Epistle to the Hebrews emphasized this fact in his document where he dealt extensively on the superiority of Christ's supreme sacrifice, (Acts 7-10).

\section{Secularity in New Testament Perspective}

In some of the New Testament documents e.g. the Epistle to the Romans affirms the validity that there is secularity in any human existence. Hence, the Christian religion should not be detached from relating to her immediate environment. It may seem strange to deeply committed Christians to learn from Paul that the church should pay absolute obedience to the civil power especially in Roman 13. But, in point of fact, this is a commandment that runs through the whole New Testament. In 1 Tim. 2: 1-2, we have,

I urge that supplications, prayers, intercessions, and thanksgivings be made for all men, for kings and for all who are in high positions, that we may lead a quiet and peaceable life, godly and respectful in every way.

So also Titus 3: 1 gives advice to the preacher: "Remind them to be submissive to rulers and authorities. To be obedient, to be ready for any honest work."

In 1 Pet. 2: 13-17 we read:

Be subject for the Lord's sake to every human institution, whether it be to the emperor as supreme or to governors as sent by him to punish those who do wrong and praise those how do right for it is God's will that by doing right you should put to silence the ignorance of foolish men... Honour all men, Love the brotherhood fear God, Honour Emperor.

We might be tempted to argue that these passages come from a time when the Roman Government had not begun to persecute the Christians. We know, for instance, in the Book of Acts that frequently, as Gibbon had it, the tribunal of the pagan magistrate was often the safest against the fury of the Jewish Mob [15]. Justin Martyr (Apology 1: 17) writes "everywhere, we more readily than all men, endeavour to pay to those appointed by you the taxes, both ordinary and extraordinary, as we have been taught by Jesus. We worship only God, but in other things we will gladly serve you, acknowledging you as kings and rulers of men, and praying that, with you kingly power, you may be found to posses also sound judgement” [15].

Tertullian says "we offer prayer for the safety of our princes to the eternal, the true, the living God, whose favour, beyond all other things, they must themselves desire... Without ceasing for our entire emperor we offer prayer. We pray for life prolonged, for security to the empire; for protection for the imperial house; for brave armies, a faithful senate, a virtuous people, the world for peace... whatever as man or Caesar, an emperor would wish” [15] [16]. He goes on to say that Christians cannot but look up to the emperor because he "is called by our Lord to his office" and he ends by saying that Caesar is more of ours than yours because our God appointed him [15] [16].

It was the consistent and official teaching of the Christian Church that obedience must be given to, and prayers made for, the civil power, even when the wielder of that civil power was Nero. In the New Testament context, to the state a man owes protection. It was the platonic idea that the state existed for the sake of justice and safety and secured for a man's security against wild beast. As state is essentially a body of men who have covenanted together to maintain certain relationship between each other by the observance of certain laws. To the state, ordinary people owe a wide range of services which individually they could not enjoy. It would be im- 
possible for every man to have his own water, light, sewage, transport system. These things are obtainable only when men agree to live together. It would be quite wrong for a man to enjoy everything the state provides and to refuse all responsibility to it. That is one compelling reason why the Christian is bound in honour to be a good citizen and to take his apart in all the duties of citizenship. St. Paul's main view of the state was that the Roman Empire, the divinely ordained instrument to save the world from chaos. Take away the Empire the world would disintegrate into flying fragments. It was in fact the PaxRomana, the Roman Peace, which gave the Christian missionary the chance to do his work [15] [16].

Ideally, men should be bound together by Christian love, but they are not, and the cement which keeps them together, is the state. St Paul saw in the state an instrument in the hand of God, preserving the world from chaos. Those who administer the state were playing their part in that great task. Whether they knew it or not they were doing God's work, and it was the Christian duty to help and not to hinder.

\section{Religion and Secularity: The Contemporary Experience}

As mentioned earlier in this paper, religion is as old as man. God created man for a purpose. The purpose is to relate with him in praise and worship and also to relate with the society to which man belongs in a more positive way which can enhance peaceful co-existence.

A society is made up of a number of individuals who are bound together by the norm of that society. Hence, any religionist cannot be so independent from the secular world to which he belongs. The New Testament confirms that this is Jesus teachings on the place of a true believer in any given environment. The Sermon on the Mount (Matt. 5 - 7) confirms the ideals Jesus expects from a Christian vis-à-vis the society where he lives. A Christian as a religionist has a vital role to play in bringing sanity to the secular world he belongs while on the other hand the Christian is expected to enjoy certain amenities and privileges which are provided by the state. It is obvious that one cannot do without the other.

When Christian religion was introduced into African culture, educational institutions and health facilities accompanied it. This contributed immensely to civilization in Africa as a whole.

With today's rapid changes in political, social, economic, moral and spiritual sphere, the attitude of religionists toward secularity has somewhat become more positive. Encounter and dialogue between religious ideologies and secularity has become a human imperative. In Africa today, many have realized as never before what it means to possess a past and a spiritual heritage untrammeled by the changes and chances of the present [17]. By implication, the contemporary experience of a religionist affords him a better understanding of the mysteries behind the nature of man and his relationship to his God. An adage says "Experience is the best teacher". If this is true to life, secularity makes religion more meaningful to the adherent.

The experience in recent times in higher institutions with regards to cultism is an eye opener that education in secular environment exposes the young ones to danger of the influence of secret cults. Even if a student who is from a good Christian background tries to live an independent life cut off from any bad influences, the fear is still there that he is in a secular environment. He has to be careful not to allow the secularity of the environment to have effect on him in a negative way.

It is a biblical fact that a Christian should not serve two masters (cf Matt. 6: 24), if it happens it is syncretism [18]. Today the society is so infected with cultism. Public and private renunciation of membership of secret cults should be encouraged so that intending members will desist from pursuing their intention [18] [19]. Gradually sanity will be restored into our society.

Another big challenge today is homosexuality in the secular world; homosexuality is not seen as a sin. In fact, in Christian religion, especially in the western world, some priests are homosexuals and they promote this among their church members. This is what all religions should detest because it is unholy and unbiblical [18]-[20].

The issue of HIV/AIDS scourge is very much on the air today. The presence of HIV/AIDS is a threat to all religionists because this pandemic disease is spreading fast more especially in the secular world. It is a moral issues which all religions emphasise to the adherents. In Helen Jackson"s view, "the development of the HIV/ AIDS epidemic is being closely monitored worldwide. Surveillance is carried out to assess its seriousness, to see how and where it is spreading and to increase international awareness of the medical, social, economic, political and other problems HIV/AIDS causes” [21]. This should lead to greater HIV/AIDS awareness and better preventive measures, to earlier production of a vaccine and curative treatments and to greater support and understanding for those who have the virus. We are grateful that World Health Organisation (WHO) has established a 
global programme on HIV/AIDS and is advising countries how to address the many different problems linked with HIV/AIDS. The Federal Government of Nigeria is not left out in this campaign. It is pertinent that the secular nature of the world has enhanced the scourge of HIV/AIDS to some extent. In Helen Jackson"s view, "Promiscuity, prostitution and immorality have promoted the spread especially in the western world" [21] [22]. But today with the approach of the church in mounting a serious campaign against HIV/AIDS there is hope that the spread will reduce. For instance, in some Churches today, couples will no more be joined together in holy matrimony unless they have HIV tests and proved negative. This will definitely check the menace in that particular society.

Bribery and corruption are part of the social evils that have eaten deep into the fabrics of our national life in Africa. They are both seen as a norm in some of African Societies. It is a stigma on the image of the world. This has made some countries to lose their credibility on the global level. It cuts across all facets of human life, economic, social, political even religious. Certificate rackets, falsification of results, presentation of false credentials, impersonation are all being experienced today not only among the youths but also among our political leaders. Religion negates this practice. The pity of it is that those who claim to be religious leaders in certain quarters are equally involved in this menace. If all religions have tenets and have standards to maintain, then these social evils should not exist in any given society. Every human being believes in one thing or the other, even agnostics and atheists who claim not to believe in anything believe in something. The mere fact that they refer to themselves as agnostic or atheists presupposes that they have allegiance to a kind of philosophy which may not be called a religion but a kind of belief that satisfies their needs. Hence, religion today should always conscientise the secular world if the purpose of creation has to be eternally fulfilled.

\section{Conclusion}

This paper has attempted to identify areas where religion can help to instill sanity into the secular world and where the secular world is expected to fulfill her role to make human existence more meaningful. I hope it will be a source material for further study on what secularity is and what relationship it has with the religious world.

\section{References}

[1] Richards, L.O. (1977) Religion. In: Expository Dictionary of Bible Words, Zondervan, Publishing House, Michigan, 519.

[2] Parinder, G. (1971) Man and His Gods. In: Encyclopedia of the World Religions, The Hamlyn Publishing Group Ltd., London, 9.

[3] Parinder, G. (1971) Man and His Gods. In: Encyclopedia of the World Religions, The Hamlyn Publishing Group Ltd., London, 10.

[4] Parinder, G. (1971) Man and His Gods. In: Encyclopedia of the World Religions, The Hamlyn Publishing Group Ltd., London, 11.

[5] Parinder, G. (1971) Man and His Gods. In: Encyclopedia of the World Religions, The Hamlyn Publishing Group Ltd., London, 12.

[6] Durkheim, E. (1912) The Elementary Forms of Religious Life. In: Jones, R.A., Ed., Emile Durkheim: An Introduction to Four Major Works, Sage Publications, Inc., Beverly Hills, 115-155.

[7] Smith, R.G. (1966) The History of the Term “Secular”. Collins Clear Types Press, London, 141.

[8] Smith, R.G. (1966) The History of the Term “Secular”. Collins Clear Types Press, London, 142.

[9] Smith, R.G. (1966) The History of the Term “Secular”. Collins Clear Types Press, London, 149.

[10] Cox, H. (1965) The Biblical Sources of Secularization: The Secular City. S.C.M. Press Ltd., London, 17.

[11] Cogarten, F. (1956) Verhanguis and Hoffnug der Neuezeit. S.C.M. Press Ltd., London, 67.

[12] Cox, H. (1965) The Biblical Sources of Secularization: The Secular City. S.C.M. Press Ltd., London, 18.

[13] Haring, B. (1974) Sin in the Secular Age. St. Paul Publications, Slough, xiii.

[14] Collins, R.F. (1992) The Formation of the New Testament: Introduction to the New Testament. S.C.M Press, London, 14.

[15] Barclay, W. (1975) The Christian and the State: The Letter to the Romans. St. Andrew”s Press, Edinburgh, 171.

[16] Barclay, W. (1975) The Christian and the State: The Letter to the Romans. St. Andrew”s Press, Edinburgh, 172. 
[17] Ekechukwu, A. (1982 \& 1983) Historical Development of the Theology of Non-Christian Religions in the Catholic Though. In: Abogunrin, S.O., Lasebikan, G.L. and Osun, G.O., Eds., Christian Presence and West African Response through the Years, Proceeding of WATTI Conference, August 1982 and 1983, 153.

[18] Igbari, S. (2000) Mission and Evangelism in the Church of the New Millennium. A Paper Presented to Immanuel College, 10.

[19] Igbari, S. (2000) Mission and Evangelism in the Church of the New Millennium. A Paper Presented to Immanuel College, 12.

[20] Igbari, S. (2000) Mission and Evangelism in the Church of the New Millennium. A Paper Presented to Immanuel College, 13.

[21] Jackson, H. (1988) AIDS ACTION NOW: Information, Prevention and Support. Aids Counselling Trust, Harare, 7.

[22] Jackson, H. (1988) AIDS ACTION NOW: Information, Prevention and Support. Aids Counselling Trust, Harare, 50. 